Performance of red tilapia in three different levels ... (Didik Ariyanto)

\title{
PERFORMANCE OF RED TILAPIA IN THREE DIFFERENT LEVELSOF SALINITY
}

\author{
Didik Ariyanto*)\# and Muslikhin ${ }^{* *}$ \\ *) Research Institute for Freshwater Fish Breeding and Aquaculture \\ ${ }^{*}$ Faculty of Science and Techniques, J end. Soedirman University
}

(Received 6 May 2011; Accepted 26 July 2011)

\begin{abstract}
Tilapias are indigeneous species to Africa, but interest in their aquaculture potential has led to nearly worldwide distribution of the species within the past fifty years. The most popular species of tilapias cultured in the world is Oreochromis niloticus. Red tilapia, one of tilapia varieties, is a highly valued commodity in global market. Based on this reason, red tilapia culture should be developed to supply the market demand. Tilapias can be culturred in brackishwater ponds due to its tolerant ability to saline water. This study was carried out to know the potential of tilapia especially the NIFI red tilapia cultured in saline water. The seeds of NIFI red tilapia were reared in three levels of salinity, i.e. 10,20 , and 30 ppt with 0 ppt as the control population. The experiment was conducted in wet laboratory for 56 days. The results showed that the difference of salinity level did not affect the performance of NIFI red tilapia, including specific growth rate, survival rate, total biomass, and food conversion ratios. Based on these results, it is suggested that NIFI red tilapia can be cultured in saline waters.
\end{abstract}

KEYWORDS: NIFI red tilapia, salinity level, performance

\section{INTRODUCTION}

Tilapias (Oreochromis) are indigenous species to Africa. However, the interest in their aquaculture potential has led to nearly worldwide distribution within the past fifty years. Increases in consumption of tilapia worldwide are the result of more consumer recognition, improved quality, variety of products, better marketing, and overall increased demand for fish products (Fitzsimmons, 2000). In 2008, China is the number one of producer of world tilapia, followed by Egypt and Indonesia (Fitzsimmons, 2009).
In Indonesia, tilapia is one of the most popular species cultured by fish farmers. The Indonesian Ministry of Marine and Fisheries has listed tilapia as one of the ten major commodities for development aquaculture. The ten commodities are seaweed, shrimp, grouper, sea bream, Asian catfish, African catfish, tilapia, milk fish, common carp, and giant gouramy (Ditjen Perikanan Budidaya, 2010). It is hoped that these commodities can increase the aquaculture production up to $353 \%$ in 2014 . Based on this target, some strategies should be conducted such as improvement in aquaculture technology, sustainable supply of high qual-

\# Corresponding author: Research Institute for Freshwater Fish Breeding and Aquaculture, Jl. Raya 2 Sukamandi, Subang 41256, West Java, Indonesia. Tel.: + 62260520500 E-mail address: didik_ski@yahoo.com 
ity of seed, and the development of culture areas.

High quality of seed can be provided through genetic improvements program followed by mass production of the seed in certified breeder farms. In the genetic improvement program, the breeders have to select the species to be cultured in a specific location. Selection of the precise species which will be adapted in a specific location is one of the key success in aquaculture activity (Tave, 1996).

In terms of culture areas development, idle or low productivity areas, such as brackishwater ponds can be used for tilapia culture. Tilapia is one of freshwater species which has the ability to tolerate certain salinity levels (Popma \& Masser, 1999). Making use of idle brackishwater ponds for tilapia culture has 2 advantages, firstly the productivity of idle ponds can be revitalized and in the same time the production of tilapia cultured can be increased. For this purpose, this study was conducted to evaluate the performance of NIFI red tilapia reared in different levels of salinity. The result was expected to be able to describe the potential of NIFI red tilapia as a candidate fish to be cultured in brackishwater or saline water ponds.

\section{MATERIALS AND METHOD}

\section{Origin of Stock}

Fish population used in this study was NIFI red tilapia collected by the Research Institute for Freshwater Fish Breeding and Aquaculture (RIFFBA) from CPP's farm in Pabuaran, Subang, West Java in 2007. The population was transferred to Sukamandi station where the male and female were reared in separate ponds. The fish used in this experiment was NIFI red tilapia seed with size ranged from 3 to $5 \mathrm{~cm}$ obtained from the $3^{\text {rd }}$ generation of the population.

\section{Methods}

\section{Experimental Design}

The experiment was conducted with complete random design with 4 levels of treatment. The treatment was level of salinity, i.e. 10, 20, 30 ppt with 0 ppt was used as the control. Each treatment was conducted in 4 replication. This experiment was carried out in the Aquaculture Technology Laboratory, Research Institute for Freshwater Fish Breeding and Aquaculture.

\section{Selection of Broodstock for Seed Production}

To produce the seed, the broodstocks were collected from both of male and female population in the ponds. The number of broodstocks selected for male and female were 10 and 20 individual, respectively. The male and female of selected broodstocks were then conditioned separately in different ponds for 2 weeks. Along this time, the selected broodstocks were fed three times daily with a commercial pelleted feed with a dietary protein level of $40 \%$ enriched with vitamin $C$ and $\mathrm{E}$, at the rate of $3 \%$ of their total biomass.

After two weeks, both male and female broodstocks were spawned in a concrete pond sized $5 \mathrm{~m} \times 5 \mathrm{~m}$ with $40-50 \mathrm{~cm}$ of water depth. The larvae were collected 2 weeks after the broodstocks pooled. The collection of larvae was conducted with micronet within one week after hatching. The collected larvae from spawning pond were then reared in 10 units aquaria sized $60 \mathrm{~cm} \times 40 \mathrm{~cm} \times 40 \mathrm{~cm}$. Density applied for the larvae rearing was 5 individual fish per liter, equivalent to 300 larvae per aquarium. For the first two weeks, the larvae were fed with a commercial powdered feed with a dietary crude protein level of $40 \%$ ad satiation. The feed was given to the larvae 5 times daily.

After two weeks, the seeds from each aquarium were transferred to 10 unit happas sized $2 \mathrm{~m} \times 2 \mathrm{~m} \times 1.5 \mathrm{~m}$ installed in an earthen pond. The water depth in each happa was 80 $100 \mathrm{~cm}$. For 1 month period, the seeds were fed three times daily with a commercial crumbled feed with a dietary crude protein level of $32 \%$ ad satiation.

\section{Acclimation of Seed in Saline Waters}

NIFI red tilapia seed was adapted to saline medium before placed into six units of fiberglass container volume 100 liters. In this period, all seeds were separated into four populations. In the first day, three populations of seed were adapted to five ppt and followed to 10 ppt on the second day. On the third day, two of those three populations were adapted to 15 ppt and followed by 20 ppt on the fourth day. On the fifth day, one of those two populations was adapted to 25 ppt and followed by 30 ppt on the sixth day. On the seventh day, all populations were placed in 16 units of fiberglass container which have been prepared 
for the treatment. Each container was equipped with active aeration provided by electric hiblower. The observation of the fish was started on the third day.

\section{Rearing of Seed}

The stocking density of NIFI red tilapia seeds was five individual per liter, equivalent to 100 fish per container. The fish was reared in the fiberglass containers for 56 days. Within this time, all fish were fed with commercial pelleted feed with a dietary crude protein of $28 \%$ Feeding rate about 5\%from the total biomass was applied with feeding frequency three times each day. Sampling of average individual body weight was conducted every 14 days. To maintain water quality, siphoning and water exchanged about $20 \% 30 \%$ were conducted every three days. Following a rearing period of 56 days, all fish were harvested and immediately several performance parameters were observed and recorded.

\section{Parameters Observed}

\section{Body Weight and Biomass}

Thirty samples from each population and replication were randomly weighed for average body weight analysis. Total biomass of each population was estimated based on the average of individual body weight multiplied with the number of survived fish at the harvest time.

\section{Specific Growth Rate}

Specific growth rate (SGR) was analyzed based on the body weight of each population, with equation as follows:

$$
\mathrm{SGR}=\frac{\ln \mathrm{Wt}-\operatorname{Ln} \mathrm{Wo}_{\mathrm{O}}}{\mathrm{t}} \times 100 \%
$$

where:

$\mathrm{SGR}=$ Specific growth rate (\% day)

Wt = Average body weight of fish at the end of experiment $(\mathrm{g})$

Wo = Average initial body weight of fish ( $g$ )

$\mathrm{t}=$ Experiment periods (day)

\section{Survival Rate}

Survival rate (SR) of each treatment was analyzed with equation as follows:

$$
\mathrm{SR}=\frac{\mathrm{Nt}}{\mathrm{No}} \times 100 \%
$$

where:

$\mathrm{SR}=$ Survival rate

$\mathrm{Nt}=$ Number of individual fish at the end of experiment

No $=$ Number of initial individual fish

\section{Food Conversion Ratios}

Food conversion ratios (FCR) were estimated by NRC (1977) equation as follows:

$$
\mathrm{FCR}=\frac{\mathrm{F}}{\mathrm{Wt}-\mathrm{Wo}} \times 100 \%
$$

where:

$\mathrm{F} \quad=$ Total number of given feed $(\mathrm{g})$

Wt $=$ Average of body weight of fish at the end of experiment $(\mathrm{g})$

Wo = Average of initial body weight of fish ( $g$ )

\section{Supporting Data}

For supporting data, water quality parameters, i.e. level of salinity, dissolved oxygen, temperature, and ammonia were also monitored once a week.

\section{Data Analysis}

All data including individual body weight, specific growth rate, survival rate, and food conversion ratios were analyzed with analysis of variance (ANOVA). Duncan's multiple range test (DMRT) was used to identify the differences among all populations. Water quality parameters were described to support the experiment results.

\section{RESULTS AND DISCUSSION}

Growth performance of each population of NIFI red tilapia for 56 days rearing period in this experiment is shown in Figure 1. The figure shows that NIFI red tilapia reared in higher salinity has a better growth than that of in the lower salinity.

At the end of the experiment, all of populations and replications were harvested. Some parameters representing the performance of the population and replications were analyzed and presented in Table 1.

Based on the analysis of variance, except body weight parameter, all of the parameters did not show significant difference $(P>0.05)$ among all treatments. This result indicates that NIFI red tilapia is an euryhaline species which can be reared in a wide range of salinity 
Indonesian Aquaculture Journal Vol.6 No.2, 2011

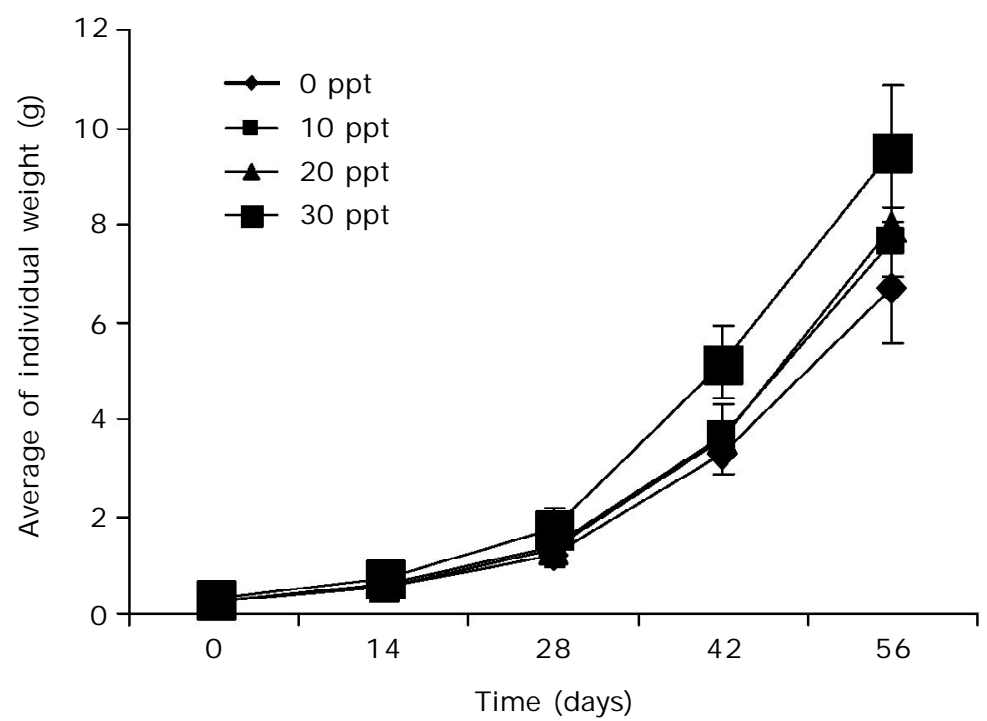

Figure 1. Growth performance of four populations of NIFI red tilapia reared in different levels of salinity

Table 1. Performance of NIFI red tilapia reared in three different levels of salinity and the control for 56 days

\begin{tabular}{cccccc}
\hline Treatments & $\begin{array}{c}\text { Body } \\
\text { weight } \\
(\mathbf{g})\end{array}$ & $\begin{array}{c}\text { Specific } \\
\text { growth } \\
\text { rate (\%) }\end{array}$ & $\begin{array}{c}\text { Survival } \\
\text { rate } \\
\mathbf{( \% )}\end{array}$ & $\begin{array}{c}\text { Biomass } \\
\mathbf{( g )}\end{array}$ & $\begin{array}{c}\text { Food } \\
\text { conversion } \\
\text { ratio }\end{array}$ \\
\hline $0 \mathrm{ppt}$ & $6.71 \pm 1.15^{\mathrm{a}}$ & $5.76 \pm 0.31^{\mathrm{a}}$ & $99 \pm 1.2^{\mathrm{a}}$ & $331.90 \pm 55.96^{\mathrm{a}}$ & $0.97 \pm 0.20^{\mathrm{a}}$ \\
$10 \mathrm{ppt}$ & $7.65 \pm 0.70^{\mathrm{a}}$ & $6.04 \pm 0.22^{\mathrm{a}}$ & $98 \pm 2.8^{\mathrm{a}}$ & $375.48 \pm 43.16^{\mathrm{a}}$ & $0.93 \pm 0.03^{\mathrm{a}}$ \\
$20 \mathrm{ppt}$ & $7.92 \pm 1.17^{\mathrm{ab}}$ & $6.36 \pm 0.34^{\mathrm{a}}$ & $96 \pm 4.3^{\mathrm{a}}$ & $378.88 \pm 47.42^{\mathrm{a}}$ & $0.84 \pm 0.07^{\mathrm{a}}$ \\
$30 \mathrm{ppt}$ & $9.48 \pm 1.39^{\mathrm{b}}$ & $6.36 \pm 0.59^{\mathrm{a}}$ & $94 \pm 4.9^{\mathrm{a}}$ & $447.12 \pm 81.70^{\mathrm{a}}$ & $1.00 \pm 0.25^{\mathrm{a}}$ \\
\hline
\end{tabular}

Values are the average from four replicates \pm standard of deviation. The same superscripts in the same column show not significantly different $(P>0.05)$

levels. High performance of NIFI red tilapia in this experiment was suspected not only due to its tolerance ability in saline water, but also due to the high quality of the rearing media. To verify this assumption, water quality parameters of the media in this experiment are presented in Table 2.

Based on Table 2, all parameters of water quality during the experiment period were suitable and optimum for seed of tilapia rearing (Boyd, 1990). Optimum condition of the medium in this experiment constitutes the high performance of the seed, such as the finally body weight, specific growth rate and survival rate.

\section{Growth Rate}

NIFI red tilapia relatively has a better performance in higher level of salinity (Up to 30 ppt), indicated by its individual body weight, specific growth rate, and total biomass. NIFI red tilapia grow faster in higher level of salinity in this experiment, which is consistent with the results obtained by Hoa (1996). Similar results were also reported in monosex Florida red tilapia (Watanabe et al., 1988, Watanabe et al., 1993), O. mossambicus (Villegas, 1990), O. mossambicus x O. hornorum hybrid (Garcia \& Sedjro, 1987, cited in Watanabe et al., 1993), mixed-sex Taiwanese red tilapia (O. mossambicus $x$ O. niloticus hybrid) (Liao \& 
Performance of red tilapia in three different levels ... (Didik Ariyanto)

Table 2. Water quality parameters of the media for red tilapia rearing

\begin{tabular}{ccccc}
\hline Treatments & $\begin{array}{c}\text { Dissolved } \\
\text { oxygen } \\
(\mathbf{m g} / \mathbf{L})\end{array}$ & $\begin{array}{c}\text { Temperature } \\
\left.\mathbf{(}^{\circ} \mathbf{C}\right)\end{array}$ & $\mathbf{p H}$ & $\begin{array}{c}\text { Ammonia } \\
(\mathbf{m g} / \mathbf{L})\end{array}$ \\
\hline $0 \mathrm{ppt}$ & $3.91-6.54$ & $26.7-29.5$ & $7.06-8.75$ & $0.022-0.980$ \\
$10 \mathrm{ppt}$ & $3.41-6.64$ & $26.9-29.4$ & $6.86-8.37$ & $0.010-0.983$ \\
$20 \mathrm{ppt}$ & $3.81-6.73$ & $27.1-29.5$ & $6.55-8.37$ & $0.026-0.847$ \\
$30 \mathrm{ppt}$ & $3.29-6.48$ & $27.1-29.5$ & $6.61-8.16$ & $0.031-0.848$ \\
\hline
\end{tabular}

The range values were resulted from the lowest and highest of each parameter observed for 56 days experiment period

Chang, 1983), and $F_{1}$ hybrid of O. mossambicus $x$ O. niloticus (Villegas, 1990). Higher performance of these species might be caused by several factors such as fish genetics, physiology, and behavior.

Organism response to the environments changes, such as salinity level, was controlled by specific genes. Trewavas (1982) cited in Haetami et al. (2008) suspected that red tilapia is a hybrid population formed from natural crossing between Mozambique tilapia (O. mossambicus) or Nile tilapia (O. niloticus) with blue tilapia (O. aureus), O. hornorum or O. zilli. Popma \& Masser (1999) explained that blue tilapia grows well in brackishwater up to 20 ppt salinity, and the Mozambique tilapia grows well at salinities near or at full strength seawater. Based on these results, it can be concluded that NIFI red tilapia has a high potential to be cultured in brackishwater pond which has salinity level up to $30 \mathrm{ppt}$. Not significantly different of the specific growth rate among all treatments of NIFI red tilapia in this study shows that NIFI red tilapia genetically has a high tolerance ability in saline water.

High performance of NIFI red tilapia in this study is also due to its physiological ability. Jobling (1994) explained that energy budget for osmoregulation can be minimized if the organism was reared in the iso- osmotic medium. In this condition, the use of energy obtained from feed could be effectively used to support a high speed of growth. Kuwaye et al. (1995) reported that Mozambique tilapia (O. mossambicu) reared in saline water has a better growth rate than in fresh water culture. Popma \& Masser (1999) explained that Nile tilapia is the only saline tolerant species among the commercially important freshwater species, and grows well at salinities up to $15 \mathrm{ppt}$.
Nandlal \& Pickering (2004) also explained that Nile tilapia may grow well in 30 ppt if it is acclimatized gradually. Andria et al. (2009) also reported that iso- osmotic condition between the physiologies interns of 'BEST tilapia' a new type released tilapia in Indonesia with the level of salinity of medium would be increased the growth rate of this fish. Those phenomenon suspected be there in this study. NIFI red tilapias reared in higher level of salinity have lower osmotic regulation. It means that the use of energy for osmoregulation mechanism was low and the surplus energy can be diverted to the building block of the body. Fish needs lower energy for osmoregulation mechanism in isoosmotic medium compared to either hypo or hyper- osmotic media.

Besides that, Febry \& Lutz (1987), Watanabe et al. (1988) and Liao \& Chang (1983) proposed that non- osmoregulatory factors such as territorial aggression and inhibitory effects of aggressive behavior which vary among different salinities might also influence the growth performance of tilapia cultured in saline water. Territorial aggression might account for onethird to one- half of the active metabolic rate in teleosts during intense contesting (Brett \& Groves, 1979). Watanabe et al. (1988) also attributed the increased growth they found with increasing salinity for Florida red tilapia to increased food consumption. NIFI red tilapias reared in the higher levels of salinity in this study consumed relatively more of feed.

\section{Survival Rate}

Tolerance ability of red tilapia to saline water was reported by several researchers, such as Nugon (2003), D'Cota et al. (2006), Listiyo wati et al. (2009), Pongthana et al. (2010). Survival rate of NIFI red tilapia in this study 
was up to $90 \%$ This result showed that NIFI red tilapia has high tolerance ability to saline water and high potential to be cultured in brackishwater or saline water. Based on this result, idle brackishwater ponds could be reused for tilapia culture areas. Culturing NIFI red tilapia which has high tolerance ability to saline water in idle brackishwater ponds can be expected to increase the national tilapia production. There are many areas of idle brackishwater ponds, such as abandoned ponds of tiger prawn (P. monodon) culture in Sumatra, Java, Kalimantan, and Sulawesi.

\section{Food Conversion Ratios (FCR)}

FCR was determined by nutritional feed intake and the ability of fish to digest and absorb the nutrients (Zoneveld, 1991). The low FCR in this study indicated that, 1) NIFI red tilapia has a high ability to digest and absorb the feed nutrition and 2) the commercial feed used in this study has a high quality. FCR in this study was not significantly different among all treatments. This result shows that different levels of salinity did not affect the ability of fish in terms of digesting and absorbing the nutrient of the feed. Both of high quality of feed and the ability of fish to digest and absorb the feed nutrition constituted the high performance of fish in this study.

\section{CONCLUSION}

Different levels of salinity did not affect the performance of NIFI red tilapia. Based on this study, NIFI red tilapia has a high potential to be cultured in brackishwater ponds with salinity level up to $30 \mathrm{ppt}$.

\section{ACKNOLEDGEMENTS}

We deeply thanks to Mrs. Nunuk Listiyowati, the Director of Tilapia Team in RIFFBA, Sukamandi for providing NIFI red tilapia population used in this experiment, and to $\mathrm{Mr}$. Bambang Gunadi, the Head of Aquaculture Technology Laboratory for allowing us to use the equipments and facilities during the research. We would also thanks to all technicians who had helped us during this experiment. Finally, we thanks to the reviewers and editors for constructive comments to improve the manuscript.

\section{REFERENCES}

Andria, V.T.A., Ath-Thar, M.H.F., \&Gustiano, R.
2009. Keragaan benih ikan nila "BEST" pada berbagai salinitas berbeda. Prosiding Forum Inovasi Teknologi Akuakultur. Pusat Riset Perikanan Budidaya, p. 107- 111.

Boyd, C.E. 1990. Water Quality in Pond for Aquaculture. Alabama: Auburn University Press, 482 pp.

Brett, J.R. \& Groves, T.D.D. 1979. Physiological energetics. In: W.S.Hoar, D.J. Randall and J.R. Brett (Editors). Fish Physiology. Academic Press, New York, 8: 279- 352.

D'Cota, H., Pepey, E., Tine, M., Ouattara, N., Baroiller, J.F., Bezault, E., Durand, J.D., Bonhomme, F., Charmantier, G., Morissens, P., Poivey, J.P., \& Chevassus, B. 2006. Adaptation to extreme salinity variation of tilapias. Symposium COA/INRA Scientific Cooperation in Agriculture, Tainan (Taiwan, R.O.C.). November, p. 7- 10.

DJPB. 2010. Production Target of National Fish Culture. Technical Meeting of Agency for Marine Affairs and Fisheries. Surakarta, November 6- 8. In Indonesian.

Febry, R. \& Lutz, P. 1987. Energy partitioning in fish: The activity- related cost of osmoregulation in a euryhaline cichlid. J. Exp. Biol., 128: 63- 85.

Haetami, K., Susangka, I., \& Maulina, I. 2006. Suplementasi Asam Amino Pada Pelet Yang Mengandung Silase Ampas Tahu dan Implikasinya Terhadap Pertumbuhan Benih Ikan Nila GIFT (Oreochromis niloticus). Laporan Penelitian. Fakultas Perikanan dan Ilmu Kelautan. Universitas Padjajaran, Bandung.

Hoa, N.P. 1996. Effects of salinity on fertilization for tilapia culture. M.Sc. Thesis. Asian Institute of Technology, Bangkok, Thailand.

Jobling, M. 1994. Fish Bioenergetic. Chapman and Hall, London, $155 \mathrm{pp}$.

Kuwaye, T.T., Okimito, D.K., Shimoda, S.K., Howerton, R.D., Hoa- Ren, L., Pang, P.K.T., \& Grau, E.G. 1993. Effect of $17 \alpha$ - methyltestosterone on the growth of euryhaline tilapia, Oreochromis mossambicus, in freshwater and in seawater. Aquaculture, 113: 137- 152.

Liao, I.C. \& Chang, S.L. 1983. Studies on the feasibility of red tilapia culture in saline water. Proceedings of the First International Symposium on Tilapia in Aquaculture, p. 524- 533.

Listiyowati, N., Ariyanto, D., \& Kusrini, E. 2008. Keragaman pertumbuhan beberapa strain 
tilapia pada beberapa lingkungan budidaya. Prosiding Teknologi Perikanan Budidaya. Pusat Riset Perikanan Budidaya, p. 63-66.

Nandlal, S. \& Pickering, T. 2004. Tilapia fish farming in Pacific Island Countries. Tilapia hatchery operation. Secretariat of The Pacific Community, oumea, New Caledonia, 1: 14.

NRC (National Research Council). 1977. Nutrient requirement of warmwater fishes and shellfish. National Academy of Sciences. Washington, D.C., 78 pp.

Nugon, R.W. 2003. Salinity tolerance of four varieties of tilapia. Master's thesis. Louisiana State University, Baton Rouge, Louisiana, USA.

Pongthana, N., Nguyen, N.H., \& Ponzoni, R.W. 2010. Comparative performance of four red tilapia strains and their crosses in fresh and saline water environments. Aquaculture, 308: 109- 114.

Popma, T. \& Masser, M. 1999. Tilapia Life History and Biology. Southern Regional Aquaculture Center Publication No. 283.

Fitzsimmons, K. 2008. Tilapia production, innovations, and markets. $8^{\text {th }}$ Intl. Symp. on Tilapia in Aquaculture. Cairo, October, 1214, 2008.
Tave, D. 1995. Selective Breeding Program for medium Size Fish Farm. FAO Fisheries Technical Paper. 352. Rome, FAO, 122 pp.

Watanabe, W.O., Ellingson, L.J., Wicklund, R.I., \& Olla, B.L. 1988. The effects of salinity on growth, food consumption and conversion in juvenile monosex male Florida red tilapia. In: Pullin, R.S.V., Bhukaswan, T., Tonguthai, K., \& Maclean, J.L. (Eds.). The Second International Symposium on Tilapia in Aquaculture, ICLARM Conference Proceedings, 15: 515- 523.

Watanabe, W.O., Ernst, D.H., Chasar, M.P., Wicklund, R.I., \& Olla B.L. 1993. The effects of temperature and salinity on growth and feed utilization of juvenile, sex-reversed male Florida red tilapia cultured in a recirculating system. Aquaculture, 112: 309320.

Villegas, C.T. 1990. Growth and survival of Oreochromis niloticus, O. mossambicus, and their F1 hybrids at various salinities. Proceedings of the Second Asian Fisheries Society. Manila, Philippines, p. 507-510.

Zonneveld, N., Huisman, E.A., \& Boon, J.H. 1991. Prinsip- Prinsip Budidaya Ikan. Gramedia Pustaka Utama, Jakarta, 309 pp. 